\title{
Hope, self-determination and workplace learning: A multilevel study in vocational training
}

\section{Christian Wandeler, Franz Baeriswyl and Richard Shavelson}

The present study investigates hope in the context of a 4 year vocational training. The theoretical framework combines the theory of hope with core ideas of self-determination theory. The main hypothesis predict a positive relationship between general hope and the satisfaction of basic psychological needs in the learning environment at the workplace. The analysis of cross-sectional questionnaire data from 450 trainees and 58 trainers integrate the perspectives of the trainees at the individual and group levels, as well as their trainers using multilevel modeling. The results show that a substantial amount of variation in individual hope is associated with the learning environment, and provides empirical support for the hypothesized positive relationship between hope and the satisfaction of three basic psychological needs (relatedness, autonomy and competence) in the work environment. The paper concludes by recommending the creation of autonomy-supportive work environments to facilitate the satisfaction of basic psychological needs and nurture hope.

While the primary goal of vocational education and training (VET) is to develop vocational competencies, the development of personal and social competencies and the promotion of a healthy development of the person are also essential, especially because VET generally takes place during the critical developmental periods of the late teens, emerging adulthood, and young adulthood (Arnett, 2000; Sirsch, Dreher, Mayr \& Willinger, 2009). Which characteristics of workplaces help trainees to build resources and nurture their strengths? Strengths of character have been proposed to be critically important resources for organizations (Peterson \& Park, 2006). The present article focuses on the strength of hope (Snyder, 2000a), which relates to the development of vocational competencies (Wandeler, Lopez, \& Baeriswyl, in press), and the roles of various workplace factors and organizational systems toward its development in the context of VET.

Quality of learning, personal development and engagement are closely interrelated. The quality of workplace learning depends on how workplaces afford opportunities for learning and how individuals elect to engage in work activities 
and with the guidance provided by the workplace (Billett, 2001). This readiness can promote individuals' engagement, which in turn is dependent on the degree by which individuals wish to engage purposefully in the workplace. Since selfdetermination theory (SDT) (Deci \& Ryan, 1985a) has been fruitful in explaining engagement and healthy human development, the current study adopts SDT as theoretical foundation and investigates whether the perceptions of psychological characteristics of environments deemed important by SDT relate to hope in a workplace learning environment.

\section{Hope Theory}

\section{Defining Hope}

The present article employed on Snyder et al.'s (1991) hope theory (HT) as a primary foundation. Hope is defined as «the process of thinking about one's goals, along with the motivation to move toward those goals (agency), and the ways to achieve those goals (pathways)» (Snyder, 1995, p. 355). As such, hopeful thinking is goal-directed (Snyder, 2002) toward goals that are personally valued (Snyder et al., 1991). The progress in goal-attainment is monitored; the resulting emotional feedback regulates and influences behavior, as well as the two components of hope: agency and pathways thinking. Hope is not an emotion but rather a dynamic cognitive motivational system (Snyder et al., 1991). Hope does not refer to wishful thinking, as in hoping to win the lottery or hoping for good weather: hope is the confidence that one will find a way to reach one's goal despite uncertainty. Hope is related to constructs like self-efficacy, optimism, and resilience, but has been shown to be theoretically and empirically distinct (Magaletta \& Oliver, 1999; Snyder, 2002). A better idea of how these constructs interrelate is given by the characterization of the higher-order construct of psychological capital, which is characterized by: «(1) having confidence (self-efficacy) to take on and put in the necessary effort to succeed at challenging tasks; (2) making a positive attribution (optimism) about succeeding now and in the future; (3) persevering toward goals and, when necessary, redirecting paths to goals (hope) in order to succeed; and (4) when beset by problems and adversity, sustaining and bouncing back and even beyond (resilience) to attain success» (Luthans, Youssef \& Avolio, 2007, p. 3).

In particular, self-efficacy is related to a specific task, context and domain (Bandura, 1997), while hope, as conceptualized by Snyder et al. (1991), is very general and oriented towards an as yet uncertain future, and emphasizes outcome expectancies. However, some domain-specific hope scales have been developed (job related hope, Luthans, Avolio, Walumbwa \& Li, 2005). Future studies on the domain-specifity versus domain-generality of hope-similar to those explored with the notion of self-concept (Shavelson, Hubner \& Stanton, 1976)—would be in order. 
In contrast, and unrelated to Snyder's conceptualization of hope as a cognitive motivational construct, Pekrun, Elliot and Maier (2009) see hope as one of several academic achievement emotions resulting from mastery and performance-approach goals (and, conversely, hopelessness as resulting from performance-avoidance goals; see also Dweck, 1986). In contrast, Snyder et al. (2002) see hopeful cognitions as the reason for the emergence of the different achievement motivations. The integration of the two views is beyond the scope of this article, but can be done by acknowledging the deep interconnection of cognition and emotion. On one hand Snyder's (2000a) process view of hopeful thinking, where emotions are seen as positive or negative feedback about the process of goal pursuit, can be broadened with the explicit inclusion of emotions of hope/hopelessness related to the pursued goals. On the other hand, the model of Pekrun et al. (2009) can be expanded by addressing the issue why a particular achievement motivation is prevalent. The current article focused on the cognitive components of hope following the approach of Snyder et al. (1991).

\section{Why Is Hope Important in VET and at Work?}

Research on hope has been among the initial research included under the umbrella of positive psychology (Seligman \& Csikszentmihalyi, 2000; Snyder \& Lopez, 2009). Out of 24 established character strengths (Peterson \& Seligman, 2004), hope has been found to correlate the highest with satisfaction in life in three different samples of adults (Park, Peterson \& Seligman, 2004). Moreover, hope has been linked to other positive characteristics such as mental and physical health (Snyder, 2002), self-actualization (Sumerlin, 1997), and academic and athletic performance (Curry, Snyder, Cook, Ruby \& Rehm, 1997).

The present article focuses primarily on the role of hope in the workplace. Hope has been found to be positively related with employee satisfaction and commitment (Adams et al., 2002), and manager-rated employee creativity (both directly and through the mediating role of happiness) in a sample of Portuguese individuals from various industries (Rego, Machado, Leal \& Cunha, 2009). In three different U.S. samples of employees of different job levels and industries, hopeful people have been found to be higher-performing (using objective measures), even after controlling for their self-efficacy and cognitive ability (Peterson $\&$ Byron, 2008). Furthermore, hope has been found to be positively related to performance (Luthans, Avolio, Avey \& Norman, 2007; Luthans et al., 2005; Luthans, Norman, Avolio \& Avey, 2008), satisfaction (Luthans, Youssef et al., 2007; Luthans et al., 2008), commitment (Luthans et al., 2008), and supportive climate (Luthans et al., 2008), and negatively associated with absenteeism (Avey, Patera \& West, 2006).

The Genesis of Hope

Snyder (2000a) points out the relevance of hope for a fast changing world and conceptualizes it as something that is learnable. A lack of hope is a result of not 
being taught to think in this manner or a consequence of intervening forces destroying such hopeful thought during childhood or later in life (Snyder, 2000b, 2002). The social environment plays a crucial role by modeling and coaching hopeful thinking and behavior (Snyder, 2000a). In general hope is promoted by encouraging individuals to come up with their own ideas of how to get around impediments, while adequate support should be available to learn how to cope with setbacks and gain experience finding alternative solutions (McDermott \& Hastings, 2000; Snyder, 2000a). The accumulation of experiences in an environment which fosters these characteristics should eventually lead to a core selfbelief that one is capable of generating pathways and sustaining the energy necessary to pursue goals. The relation between hope and self-efficacy is reflected by the similarity of genesis and favorable environments (Bandura, 1997). In addition to the creation of environments that foster the learning of hope, specific interventions have been developed to increase hope in individuals or teams (Lopez et al., 2004; Luthans \& Jensen, 2002).

\section{Self-Determination Theory}

\section{Three Basic Psychological Needs}

SDT is inspired by humanistic psychology (Rogers, 1961) and focuses on the social-contextual conditions that foster positive human potential, natural processes of self-motivation and healthy psychological development (Ryan \& Deci, 2000). According to SDT, humans have three innate psychological needs: competence, autonomy, and relatedness. The satisfaction of these needs leads to enhanced self-motivation and mental health. Failure to satisfy the needs typically results in diminished motivation and well-being. In workplace-related research, the satisfaction of the basic needs has been found to relate to positive outcomes such as the acceptance of organizational change (Gagné, Koestner \& Zuckerman, 2000), employee engagement (Meyer \& Gagné, 2008), and the integration of extrinsic motivation as well as maintenance of initial intrinsic motivation (Gagné \& Deci, 2005).

\section{Internalization of Extrinsic Motivation: What motivates people?}

SDT does not treat motivation as a unitary concept that varies primarily in amount and not kind (Deci \& Ryan, 2008). Instead three different types of motivation are distinguished: amotivation (not motivated), controlled motivation (behaving with the experience of pressure and demand toward specific outcomes that comes from forces perceived to be external to the self) and autonomous motivation (behaving with a full sense of volition and choice). SDT assumes that extrinsic motivation can become more autonomous when people experience the satisfaction of their basic psychological needs (Deci \& Ryan, 2008). Autono- 
mous motivation is related to psychological health, healthier lifestyles, less burnout at work (Deci et al., 2001; Deci \& Ryan, 2008); as well as work satisfaction, psychological health, and self-esteem after controlling for the extrinsic factors of pay and job status (Ilardi, Leone, Kasser \& Ryan, 1993).

\section{Bridging $H T$ and SDT}

\section{The Link between Hope, Self-concordant Goals, and Autonomous Motivation}

Work is one of the main areas of life where humans are confronted with external demands and have to pursue goals which are often externally imposed. Particularly for young trainees entering the workforce, the development of a professional identity and pride is an important part of successful socialization, which ideally coincides with developing autonomous motivation. SDT attributes the degree to which these external demands are internalized and work motivation becomes more autonomous to a combination of the satisfaction of the basic psychological needs in the social environment and individual differences (Gagné \& Deci, 2005; Millette \& Gagné, 2008). Since goals are the cognitive component that anchors hope (Snyder, 2002), the initial step of engaging in hopeful thinking at the workplace is to adopt work-related goals and to identify with them. HT does not directly address the processes of goal adoption and motives of goal pursuit. While HT focuses more on how goals are pursued, SDT distinguishes extrinsic and intrinsic forms of motivation and addresses why people pursue goals and how they identify themselves with external demands (Deci \& Ryan, 2000). SDT can thus contribute to HT by explaining which learning environments can enhance goal adoption and identification with work-related goals.

Hope is viewed as inseparable from meaning and purpose (Snyder \& Feldman, 2000). Hopeful thinking is implicitly directed towards goals which make sense to the individual and are coherent with the values of the individual. Goals that are consistent with a person's developing interests and/or core values, known as selfconcordant goals, have been found to predict higher well-being; these goals are typically pursued with more sustained effort and thus are more likely to be attained (Sheldon \& Elliot, 1999). Self-concordant goals should thus be associated with deeply rooted agency thoughts necessary to sustain the action, and spur the pathways thinking to overcome barriers in the goal attainment process. High-hope employees are likely to also be hopeful in their personal lives, because work is a prominent source of sense of purpose in life, which is strongly related to hope (Adams et al., 2002). The importance of workplace experiences was supported by the analysis of a longitudinal sample related to the current study, where perceived vocational competencies lead to increases in hope, while the trainees' hope in turn also had positive effects on the development of perceived vocational competencies (Wandeler \& Bundick, 2011). Descriptions of high-hope people and autonomy- 
oriented people converge in numerous ways (Ryan \& Deci, 2006; Snyder, $2000 a$ ), in part because "the agency component of hope involves setting realistic goals and then reaching for those goals with self-directed determination and a perception of internalized control» (Simmons, Gooty, Nelson \& Little, 2009, p. 236).

\section{Hope and the Satisfaction of Basic Psychological Needs}

Characteristics of high-hope workplaces (Adams et al., 2002) seem to satisfy the three basic psychological needs of SDT. The present study explicitly formulates the corresponding theoretical relations between the satisfaction of the three basic psychological needs and hope.

The need for competence. Hope should be nurtured by experiences of competency. First, a broadened action repertoire translates into having access to more pathways and provides individuals with resources. Second, the experiences of success, goal-attainment and overcoming of hindrances provide positive emotions and bolsters agency and pathways thinking. Third, the presence of competence implicitly suggests that one has encountered and overcome incompetence, at least in part by acquiring the competencies necessary to cope with workplace demands; this in turn should empower one to deal with further demands. Besides building up competencies, individuals also experience that obstacles can be overcome. Development of competencies in vocational training can therefore affect general hope and spill over in various life domains.

The need for autonomy. Experiencing autonomy seems to be crucial for the development of hope in the following ways. First, with increasing degrees of autonomy the possibilities for developing new pathways and influencing situations are enhanced. Being able to experiment, coming up with one's own solutions to problems without being assisted to soon or constrained through prescribed procedures brings people to apply and train hopeful thinking. Second, having autonomy translates into having a certain degree of control, which is essential to experience one's own agency. Third, by being accorded more autonomy individuals are signalled trust and confidence in their ability to master a problem and deal with difficulties. Trust and confidence in individuals, especially when they are developing and maybe somewhat doubtful towards their own capacities, can spur hope through the mechanism of social persuasion (Bandura, 1997).

The need for relatedness. Intrinsic motivation has been found to be fostered by interpersonal settings characterized by a sense of security and relatedness (Ryan \& Deci, 2000). HT research linking hope and attachment styles has suggested that secure attachment to a supportive and responsive adult facilitates the development of a young person's hopeful goal-directed thinking (Shorey, Snyder, Yang \& Lewin, 2003). Vocational training is socially situated with many interactions among trainees, trainers, and other employees. "The presence of a responsive adult who is simultaneously caring, has high expectations, and demands high levels of performance can instil hope in a developing young person» 
(Shorey et al., 2003, p. 709). The experience of relatedness creates social meaning, supports the internalizing of external demands, and facilitates social model learning. Workplace research found a significant, positive relationship of secure attachment with hope and trust (Simmons et al., 2009). Furthermore, HT highlights hope-fostering behavior (Snyder, 2000a), which mirrors one of the SDT's key concepts: autonomy support (Deci \& Ryan, 1985a), which is a manner of interaction that facilitates the satisfaction the basic psychological needs. An autonomy-supportive person or work environment would typically provide a good rationale for asking someone to engage in an activity, offer the person some choice, acknowledge the person's feelings toward the activity, and encourage the person to take initiative and convey confidence in the person's abilities (Williams, Gagné, Ryan \& Deci, 2002). Autonomy support research can give further suggestions for hope promotion.

\section{Research Questions}

The first research question involved testing the hypothesis that vocational learning environments relate to individuals' levels of general hope.

Hypothesis 1: Individual hope is meaningfully associated with the vocational learning environment (specifically, the portion of variance explained exceeds 10\%; Papaioannou, Marsh \& Theodorakis, 2004).

The second research question investigated whether the satisfaction of the basic needs, as a characteristic of the learning environment, relates positively to hope. This research question involved three separate but related hypotheses, based on the levels and sources of assessment of the needs.

Hypothesis 2a: The three individual perceived basic need satisfactions relate positively to individual levels of hope.

The relation between hope and an individual's perceived need satisfaction may potentially be inflated, because of the common method of self-report and because it is likely that hopeful trainees also perceive their situation more favourably. The directionality between hope and the needs could go either way or be bi-directional. In order to address these concerns additional data group-level data were used, which should be less influenced by self-report bias and provide more objective measures of the general VET environment. Divergences in individual perceptions of the environment were assumed to balance each other out when the different perceptions of trainees from the same learning environment are integrated. Thus, the perceptions of trainees who were guided by the same trainer were aggregated in order to form a less biased measure of the workplace environment.

Hypothesis 2b: The averages of need satisfaction of trainees in a similar vocational training environment (grouped by their vocational trainer) relate positively to individual levels of hope. 
Another independent evaluation of the general conditions in the VET environment stemmed from trainers' ratings of the potential need satisfaction of their group of trainees.

Hypothesis 2c: Trainer ratings of trainees' need satisfaction relate positively to individual levels of hope.

\section{Method}

\section{Sample}

The study took place in the framework of vocational training research in the German-speaking part of Switzerland and was restricted to one particular profession: polymechanics. Switzerland has a dual system of vocational training in which public vocational schools and mostly private companies work together to train and educate young professionals. During the four years of the polymechanic apprenticeship the trainees learn on the job at their company and attend vocational school for one or two days a week. The respondents selected for this analysis consisted of a sample of trainees $(\mathrm{N}=450)$ and their trainers at the workplace $(\mathrm{N}=58)$ from 49 different companies. Only trainers with at least three responding trainees were selected. The trainees had an average age of 18.54 years $(S D=1.30)$ and $89 \%$ were native German speakers. The trainers were on average 40.74 years old $(S D=10.71)$ and $97 \%$ were native German speakers. Only $3 \%$ of the trainees were female and only 2 trainers were female (less than 1\%).

\section{Procedure}

The potential participants were contacted through the two largest associations of the Swiss mechanical industry, which provided contact information and encouraged their members to participate. The participating trainees either filled out paper and pencil questionnaires administered by their regular trainers in the work context during work hours, or they completed an identical online version of the questionnaires if computers were available at the workplace. In order to increase motivation for a full completion of the questionnaire, gift certificates of substantial value were given away to seven randomly chosen participants. The response rate of the trainees in the contacted companies was around $80 \%$.

Measures at the trainee level. As indicators of the satisfaction of the needs for relatedness, autonomy and competence, three adapted or newly developed scales were used. A confirmatory factor analysis to test the postulated factor structure was conducted with the statistical software AMOS 6.0 (Arbuckle, 2005). The analyses reported below are based on full information maximum likelihood estimates including means and intercepts (Enders \& Bandalos, 2001; Raykov, $2005)$. The model without any correlated errors fit the data acceptably well $\left(\chi^{2}\right.$ $(17)=40.64, p<.01, \chi^{2} / d f=2.39$, RMSEA $\left.=.04, \mathrm{CFI}=.99\right)$. Factor loadings ranged from .47 to .91 and the latent factors correlated between $r=.20$ to .35 . 
Relatedness. Two items measured the trainees' perceived quality of the personal relationship with the trainers and the peers relation with the trainers (Baeriswyl, Wandeler \& Oswald, 2006), reflecting the potential for satisfying the need for relatedness in the particular vocational learning situation. These two items read as follows: «In general the relationships between trainers and trainees are very good in our company» and "My relationship with my trainer is very good.» The items were answered on a 4-point Likert-type scale ranging from 1 (definitely true) to 4 (definitely not true). The internal reliability was satisfactory $(\alpha=.78)$.

Autonomy. Originally included in Hackman and Oldham's Job Diagnostic Survey (1975), Scharnhorst, Frey et Balzer (2006) adapted a German translation to fit the targeted population of the present study ( 3 items; e.g., "My work provides me with numerous occasions to decide how to proceed.»). The internal consistency was low $(\alpha=.56)$. However, the face validity of the underlying items seemed to be sound and indicated a quite broad measure of autonomy, which should be favourable to external validity. Since unreliability attenuates regression coefficients, non-significant results may be due to unreliability.

Competence. This scale was developed by Frey and Balzer (2005) for the present project to measure self-perceived competency as a polymechanic. The trainees were asked to rate how well they performed 25 different professional skills on a 5-point Likert-type scale ranging from 1 (badly) to 5 (well) (25 items; e.g., "to produce parts by hand", "to choose the right tools and prepare them", «interpret assembling instructions»). The internal consistency of the scale was satisfactory $(\alpha=.91)$.

Hope. Hope was measured with a previously tested back-translated German version (Wandeler, 2003) of the Adult Dispositional Hope Scale (Snyder et al., 1991). The participants answered eight items on a 6-point Likert-type scale ranging from 1 (definitely false) to 6 (definitely true). Together the eight items operationalize the overarching hope construct, which consists of two subscales with four items each: pathways or ways (sample item: «Even when others get discouraged, I know I can find a way to solve the problem.») and agency or will (sample item: «I energetically pursue my goals.»). Cronbach's alpha for the hope scale was .76 and the factor structure (agency and pathways) was replicated in a principal components analysis using varimax rotation (two resulting Factors, both with eigenvalues above 1 , explained $51.9 \%$ of the total variance). The correlation between agency and pathways factors was $r=.50$, which lies in the range of correlations reported by Babyak, Snyder and Yoshinobu (1993) ( $r s=.40$ to .50).

Measures at the group level. A detailed rating of competence from the trainers for each one of their trainees was not available, but ratings for the environmental variables were obtained. Relatedness (Trainer perspective). To get an estimate of the quality of the relationships between the trainees and trainers from the perspective of the trainers, the two items of the trainee measure were adapted to fit the trainer perspective (i.e., "In general the relationship between trainers and trainees is very good in our company,» "My relationship with my trainees is very good.»; Baeriswyl et al., 2006). The two items were answered on a 4-point 
Likert-type scale ranging from 1 (definitely true) to 4 (definitely not true) and the internal consistency was low but acceptable $(\alpha=.67)$.

Autonomy (Trainer perspective). To measure the trainers' perceptions of the degree of autonomy the trainees' work situation provided, the wording of the autonomy items used for the trainees were adapted to fit the trainers' perspective (e.g., "The trainee's work provides them with numerous occasions to decide how they proceed.»). The scale consisted of 3 items and showed satisfactory internal consistency $(\alpha=.70)$.

Aggregated relatedness, autonomy and competence (Trainee group means). To reflect the perceptions of the shared learning environment, corrected for individual idiosyncrasies, scores of individual subjects were aggregated to the group level (Lüdtke, Trautwein, Kunter \& Baumert, 2006a). Intraclass correlations (ICC) were calculated in order to provide an indication of the reliability of the individual trainee's rating ICC(1) and the reliability of the aggregated trainees' rating at the class level ICC(2) (see Bliese, 2000; Lüdtke, Trautwein, Kunter \& Baumert, 2006b; Snijders \& Bosker, 1999). Lüdtke et al. (2006a) explain the ICC (1) as «the proportion of total variance that can be attributed to betweenclass differences» and "the extent to which the class-mean score is interchangeable with individual student ratings, with higher ICC(1) scores indicating higher reliability» (p.218). The ICC(1) is the variance between classes divided by the variance between classes plus the variance within classes. Lüdtke et al. (2006a) recommend to calculate the ICC $(2)$ «when it is not just a question of determining the reliability of an individual student rating, but of gauging the accuracy of a class-mean rating» (p. 218). The ICC(2) is computed like the ICC(1), but the variance within classes is divided by the average class size.

The ICC(1) scores in the present study indicated sizable differences between the groups for relatedness (.25) and small differences for autonomy (.07) and competence (.04) across the groups. The ICC(2) was .66 for relatedness. This rather high agreement of the trainees within a trainer group indicates that the group level assessment of relatedness was quite reliable. The ICC(2) for autonomy (.29) and competence (.22) were relatively low, thus indicating that the aggregated measures of autonomy and competence were not very reliable and rather large differences exist between the ratings of individuals within a group.

\section{Statistical Analyses}

As is common in research in educational and organizational contexts, the present data had a nested structure: trainees were grouped under different trainers, which in turn were nested in different companies. In comparison with other trainees, trainees of the same trainer might be more similar to each other, because they shared a similar environment or might have been selected in similar ways. Thus a consequence of the nested structure of the data could be a violation of the statistical assumption of independence of measurement. Since the group level accounted for a substantial amount of variance $(11.4 \%)$ of the dependent variable hope, and only $2 \%$ variance was at the level of companies; the hierarchical struc- 
ture of the data was taken into account, and two-level multilevel analyses were computed (Raudenbush \& Bryk, 2002). Two main advantages of multilevel models are the corrected estimates for standard errors, which reduces the probability of finding statistically significant relationships where in reality there are none (type 1 or alpha error), and to allow relationships between variables to differ across different groups (random slopes). These varying relationships in turn can be predicted by other variables (slopes as outcomes models). The hypotheses were tested with two-tailed significance tests: a conservative test, considering the clearly directed hypotheses. In order to obtain standardized regression coefficients, before performing the multilevel analyses all variables were standardized $(M=0, S D=1)$ to enhance the interpretability of the findings, because HLM 6.04 does not report standardized coefficients (Raudenbush, Bryk, Cheong \& Congdon, 2004). The regression coefficients reported herein thus indicate the proportion of a standard deviation by which the dependent variable will increase/decrease if the predictors increase/decrease by one standard deviation. All models were estimated by using the restricted maximum likelihood estimation technique (Bryk \& Raudenbush, 1992).

\section{Results}

\section{Descriptive analyses}

The descriptive statistics of the variables hope, relatedness, autonomy and competency are reported in Table 1.

Table 1: Means, standard deviations and correlations of ratings of individual trainee (1-4), trainees' mean by trainer group (5-7), and trainer (8-9)

\begin{tabular}{|c|c|c|c|c|c|c|c|c|c|c|c|c|c|c|c|c|c|}
\hline & $\mathrm{M}$ & SD & 1 & & 2 & & 3 & & 4 & & 5 & & 6 & & 7 & 8 & \\
\hline 1 Hope & 4.75 & .53 & & & & & & & & & & & & & & & \\
\hline 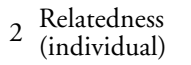 & 3.42 & .59 & .24 & *** & & & & & & & & & & & & & \\
\hline $3 \begin{array}{l}\text { Autonomy } \\
\text { (individual) }\end{array}$ & 5.11 & .95 & .23 & *** & .17 & $* * *$ & & & & & & & & & & & \\
\hline $4 \begin{array}{l}\text { Competency } \\
\text { (individual) }\end{array}$ & 4.11 & .46 & .44 & *** & .09 & & .21 & $* * *$ & & & & & & & & & \\
\hline $5 \begin{array}{l}\text { Relatedness } \\
\text { (group mean) }\end{array}$ & 3.41 & .37 & .23 & $* * *$ & .62 & $* * *$ & .16 & $* *$ & .03 & & & & & & & & \\
\hline $6 \begin{array}{l}\text { Autonomy } \\
\text { (group mean) }\end{array}$ & 5.11 & .42 & .17 & *** & .22 & $* * *$ & .44 & $* * *$ & .07 & & .35 & $* * *$ & & & & & \\
\hline $7 \begin{array}{l}\text { Competency } \\
\text { (group mean) }\end{array}$ & 4.11 & .19 & .26 & *** & .06 & & .07 & & .41 & $* * *$ & .09 & $*$ & .15 & $* * *$ & & & \\
\hline $8 \begin{array}{l}\text { Relatedness } \\
\text { (trainer) }\end{array}$ & 3.42 & .45 & .13 & ** & .21 & $* * *$ & .03 & & .05 & & .33 & $* * *$ & .06 & * & .14 & $* *$ & \\
\hline $9 \begin{array}{l}\text { Autonomy } \\
\text { (trainer) }\end{array}$ & 5.44 & .76 & .01 & & .00 & & .08 & & .00 & & -.02 & & .19 & $* * *$ & -.01 & .42 & $* * *$ \\
\hline
\end{tabular}

Note. ${ }^{*} \mathrm{p}<.05 .{ }^{* *} \mathrm{p}<.01 .{ }^{* * *} \mathrm{p}<.001$. 
The trainee and the trainer ratings of relatedness were high and at similar levels, but the trainer ratings of autonomy were higher than the average of the aggregated trainee ratings $(t(449)=8.85, p<.001)$. Hope correlated the highest with competency. The needs correlated with each other except for competency and relatedness.

The correlations between the trainers and the average of the groups of trainees indicated the degree of agreement between the ratings. These particular results showed that trainer-rated relatedness correlated significantly $(r=.33)$ with the trainees' average for relatedness, and likewise trainer-rated autonomy correlated significantly $(r=.19)$ with the trainees' mean for autonomy. Though these effect sizes were relatively small, they were higher than the correlations with the other constructs, thus providing some evidence of validity.

\section{Predicting hope with individual level variables}

The unconditional model (null model without any predictors) revealed that $11.4 \%$ of the variance of an individual's hope was associated with the group of trainees, suggesting that the vocational learning environment does relate to an individual's level of hope. Thus hypothesis 1 was supported and multilevel models were specified to account for the nested structure of the data.

In models 1-3 (see Table 2) individual hope was regressed on trainee perceived relatedness, autonomy and competence. All three indicators for need satisfaction significantly predicted hope. In order to test if the relationships between hope and needs were different in the various groups of trainees the models 1-3 were also tested with random slopes. The random slopes were not statistically significant, indicating that the relationships were similar across the different groups of trainees. Consequently all subsequent reported models are random intercepts models with fixed slopes. In model 4 hope was simultaneously regressed on all three indicators, which all independently contributed information to the prediction of hope; competence was the strongest predictor, with weaker contributions by relatedness and autonomy. Since scale unreliability can attenuate regression coefficients, the effect for autonomy could be underestimated. The models $1-4$ thus support hypothesis $2 \mathrm{a}$.

Table 2: Individual level models: prediction of hope by the satisfaction of basic needs indicators

\begin{tabular}{|c|c|c|c|c|c|c|c|c|c|c|c|c|}
\hline & \multicolumn{3}{|c|}{ Model 1} & \multicolumn{3}{|c|}{ Model 2} & \multicolumn{3}{|c|}{ Model 3} & \multicolumn{3}{|c|}{ Model 4} \\
\hline & B & & SE & B & & SE & B & & SE & $\mathrm{B}$ & & SE \\
\hline individual level & & & & & & & & & & & & \\
\hline Relatedness & .22 & $* * *$ & .05 & & & & & & & .15 & ** & .05 \\
\hline Autonomy & & & & .23 & $* * *$ & .06 & & & & .15 & ** & .05 \\
\hline Competence & & & & & & & .43 & $* * *$ & .04 & .38 & $* * *$ & .05 \\
\hline$R^{2}$ & .09 & & & .07 & & & .21 & & & .28 & & \\
\hline
\end{tabular}

Note. ${ }^{*} \mathrm{p}<.05 .{ }^{* *} \mathrm{p}<.01 .{ }^{* * *} \mathrm{p}<.001$. 


\section{Comparing group level variables}

The next model sequence (models 5-10) integrated information at the group level (trainees' means and trainer ratings), at first without controlling for any individual level predictors (see Table 3). In model 5 the group means for the basic needs were entered simultaneously at the group level. Average relatedness and competence were significant predictors of hope and explained about $10 \%$ of the total variance. Autonomy was not statistically significant. The competency average was dropped for the comparison of the different sources of information at group level (models 6-7), given that there was no rating of competency by the trainers. By dropping competency (model 6) the explained variation dropped substantively $(6 \%)$ and the group average for autonomy now reached statistical significance. Thus hypothesis $2 \mathrm{~b}$ was partially supported. For the trainer ratings (model 7) only relatedness was a marginally statistically significant predictor of hope, thus not substantially supporting hypothesis $2 \mathrm{c}$. The comparison of the different sources of group level data suggests that trainee group indicators for the environment were more related to individual trainee's hope than the information obtained from trainers.

Table 3: Individual and group level model (trainees' means, trainers): prediction of hope by the satisfaction of basic needs indicators

\begin{tabular}{|c|c|c|c|c|c|c|c|c|c|c|c|c|c|c|c|c|c|}
\hline & & Todel & & & odel & & & del 7 & & lodel 8 & & & Iodel & & & odel & \\
\hline & B & & SE & B & & SE & B & SE & B & & SE & B & & SE & B & & SE \\
\hline individual level & & & & & & & & & & & & & & & & & \\
\hline Relatedness & & & & & & & & & .10 & & .06 & .15 & $* *$ & .05 & .14 & * & .05 \\
\hline Autonomy & & & & & & & & & .14 & **. & .05 & .14 & $* *$ & .05 & .15 & * & .05 \\
\hline Competence & & & & & & & & & .38 & *** . & .05 & .34 & *** & .05 & .37 & *** & .05 \\
\hline group level & & & & & & & & & & & & & & & & & \\
\hline $\begin{array}{l}\text { Relatedness } \\
\text { (group mean) }\end{array}$ & .17 & * & .05 & .18 & ** & .06 & & & .11 & $\dagger$ & .06 & & & & .10 & & .06 \\
\hline $\begin{array}{l}\text { Autonomy } \\
\text { (group mean) }\end{array}$ & .07 & & .05 & .14 & * & .07 & & & & & & & & & -.01 & & .06 \\
\hline $\begin{array}{l}\text { Competence } \\
\text { (group mean) }\end{array}$ & .24 & & .05 & & & & & & & & & .11 & * & .05 & .11 & $\dagger$ & .06 \\
\hline Relatedness (trainer) & & & & & & & .13 & $\dagger .07$ & & & & & & & & & \\
\hline Autonomy (trainer) & & & & & & & .02 & .09 & & & & & & & & & \\
\hline$R^{2}$ & .11 & & & .06 & & & .01 & & .29 & & & .29 & & & .29 & & \\
\hline
\end{tabular}

Note. $\dagger<.07^{*} \mathrm{p}<.05 .{ }^{* *} \mathrm{p}<.01 .{ }^{* * *} \mathrm{p}<.001$.

\section{Combining trainee level and group level variables}

Models 8 through 10 combined the individual level and the group level information (see Table 3 ), thus testing hypothesis 2 b more stringently. By controlling for the perceived need satisfaction at the individual level, one can explore which additional effect the average perceived satisfaction in a trainee's group had on the 
individual's level of hope. In model 8 group-perceived relatedness was marginally significant while individual-level reported relatedness was reduced to nonsignificance. In model 9 the trainees' means of perceived competency was statistically significant. Trainees with similar need satisfaction displayed slightly higher levels of hope when the reported level of competency in their group was higher. In model 10 all trainee group indicators were added simultaneously, with competency being marginally significant. However, the explained variation increased only by $1 \%$, indicating that the individual perceptions of need satisfaction account for most of the variation.

\section{Discussion}

The hypothesized positive relationships between hope and the three basic needs variables_-relatedness, autonomy and competency_-were empirically supported with individual-level data and partially supported with group-level data. Hope was most closely linked to competency, while autonomy and relatedness were also statistically significant predictors. Accounting for almost a third of the explained variation, the strength of these relationships with hope was meaningful; the independent contributions of the constructs converge with results of previous SDT research (Ryan \& Deci, 2000), suggesting that all three needs are important toward promoting hope. The fact that perceived professional competency is the strongest predictor of hope suggests that professional experiences and development of professional skills can be an important source for hopeful thinking; as such, they likely spill over to the broader life experience. Similarly, the experience of relatedness and autonomy in the vocational context can contribute in nurturing hope beyond the workplace.

According to triadic reciprocal determination (Bandura, 2008), the individual's traits, individual's states, individual's behavior, and the situation are highly interactive. Personal characteristics not only shape perception, but actually influence the situation and elicit reactions from the environment. Self-reports are therefore probably the most appropriate indicator for a highly subjective experience; however, avoiding the common method bias of self-report remains a challenge. The self-report bias was addressed in the present study by using measures at the group level, which should be a more objective reflection of the environment. The existing relations of the perception of trainee groups with individual levels of hope should thus provide stronger support for the main hypothesis. However, the group level predictors based on the trainer ratings hardly related to individual levels of hope.

That the aggregated trainees' estimates of competency predicted individual hope after controlling for individual indicators of need satisfaction points to the general importance of providing trainees with feelings of competency in the workplace. Environments where trainees in general feel competent can thus pro- 
mote individuals' hope beyond their personal feelings of competence. HT has not extensively researched group-related processes in the development of hope. Possible explanations for these group-level effects could be contagion processes, the occurrence of social learning, and other positive social dynamics fostering hope within organisations. The average level of perceived competency could also be a proxy for the general quality of the particular vocational training, and thus reflect other qualitative characteristics of workplaces not directly measured in this study.

\section{Limitations and future research}

Causal inferences. The reported results are based on cross-sectional data and therefore no causal inferences can be made. Rather than effects of the environment, the common variance at trainee group level could result from measurement effects (e.g., similar setting when filling out the questionnaires), selection processes by the company, or self-selection. Because the aim of vocational training is to influence and shape individuals, it is more apparent to assume an influence of the context on the individual. But the reverse causal directionality is also plausible: high hope people may perceive an environment in a more positive way or actually interact with their environment in ways which lead to modified conditions with higher need satisfaction. Indeed, such reciprocal processes are assumed by SDT (Deci \& Ryan, 1985b). Likewise, HT would suggest that people with higher hope perceive their environment more positively, since it is precisely an attribute of high-hope people to see more pathways to obtain their goals and be more energetic during the goal pursuit. Future research could use longitudinal data to investigate questions about the interactions between the individual and the environment, as well as positive reinforcing feedback loops, and use experimental designs to evaluate the influence of trainer behavior and work characteristics.

The issue of confounding through self-report has been partly addressed by forming averages of trainee groups and the inclusion of trainer ratings of the general situation of their trainees. Independent ratings of the situation of each individual trainee by neutral observers might have given more objective and more reliable measures of the environmental conditions. Future research could use such independent data to address questions regarding how the subjective experience of satisfaction of basic psychological needs relates to observer-rated conditions and the role hope plays in these processes. HT also would benefit from a more thorough analysis of the effects of group processes and other workplaces characteristics.

The relation between hope and competency could be inflated, because several of the items on the hope scale address past successes. However, these items are very broad and refer to life in general, whereas the competency items measure very specific descriptions of tasks of the polymechanical profession. This distinction was also supported by confirmatory factor analyses and the better fit of a 
four scale model (hope and the three needs) versus three different three-scale models where hope was merged alternatingly with competence, relatedness and autonomy.

Reliability and validity. The measurements of competence and relatedness were quite reliable, but the trainee-reported autonomy scale had a low reliability. Autonomy has repeatedly been reported to be difficult to measure reliably (Deci, Connell, \& Ryan, 1989; Greguras \& Diefendorff, 2009).

Priming and framing effects could have inflated the degree to which workplace factors were related to general hope of young trainees, because the trainees responded at the workplace and the questionnaire was mainly focused on workrelated issues. The large, real-world sample suggests a strong ecological validity for the population of German-speaking polymechanic trainees. Although no gender-specific effects were assumed, it would be important to examine genderspecific effects of work environments. Also, the findings should be replicated with other professions (e.g., would effects between competency and hope also exist in a profession with less demanding skills?). Furthermore, older adults might show different effects than young adults, given their likely developmental differences in personalities and competencies. Future research should use specific measures developed within the SDT research to facilitate more detailed comparisons.

\section{Practical implications}

In order to promote hope, organizations should not only consider proven short-term interventions, which focus on the individual, but also strive to create enduring favorable conditions at the workplace. The satisfaction of the basic psychological needs is a feature of the workplace and the organizational culture which can create a stable positive dynamic at the organizational level to nurture hopeful thinking: trainees must feel they are becoming competent, and experience both autonomy and positive relational bases in their social environment to be optimally effective. Through autonomy-supportive behavior trainers can contribute to the satisfaction of the basic psychological needs. At the organizational level, the so-called high-involvement organization (Lawler, 1992) could be a model for promoting hope.

\section{Conclusion}

The present study found empirical support for the hypothesis that individual hope is related to group membership, suggesting a relation of workplace experiences to hope. The fact that important character strengths of young people are connected to their VET environment shows that the social context and the learning environment at work can substantially support the development of psychological strengths. By incorporating ideas of SDT into HT, the present study sug- 
gested that one of the characteristics of hope-nurturing workplaces is the satisfaction of basic psychological needs. HT and SDT can give valuable suggestions for how hope can be nurtured through favorable work environments and the hope-promoting behavior of trainers. In regard to the future development of the hope construct, this study laid out the theoretical argument that the characteristics and the self-concordance of goals affect how strong hopeful thinking is and that they provide the underlying support of meaning in which hopeful thinking is taking place. Beyond the satisfaction of basic psychological needs, the characteristics of work-related goals could thus be a central component of the beneficial effects of workplaces on hope and other character strengths.

\section{References}

Adams, V. H., Snyder, C. R., Rand, K. L., King, E. A., Sigman, D. R. \& Pulvers, K. M. (2002). Hope in the workplace. In R. A. Giacolone \& C. L. Jurkiewicz (Ed.), Handbook of workplace spirituality and organization performance (pp. 367-377). New York: Sharpe.

Arbuckle, J. L. (2005). Amos 6.0 User's Guide. Chicago: SPSS Inc.

Arnett, J. J. (2000). Emerging adulthood: A theory of development from the late teens through the twenties. American Psychologist, 55, 469-480.

Avey, J. B., Patera, J. L. \& West, B. J. (2006). The implications of positive psychological capital on employee absenteeism. Journal of Leadership and Organization Studies, 13, 42-60.

Babyak, M. A., Snyder, C. R. \& Yoshinobu, L. (1993). Psychometric properties of the Hope Scale: A confirmatory factor analysis. Journal of Research in Personality, 27, 154-169.

Baeriswyl, F., Wandeler, Ch. \& Oswald, K. (2006). Die Ausbildungskonzeptionen von betrieblichen Ausbildenden. Unpublished research report, University of Fribourg.

Bandura, A. (1997). Self-efficacy: The exercise of control. New York: W. H. Freeman \& Co.

Bandura, A. (2008). Toward an agentic theory of the self. In H. Marsh, R. G. Craven \& D. M. McInerney (Ed.), Advances in self research: Self-processes, learning, and enabling human potential (Vol. 3) (pp. 15-49). Charlotte, NC: Information Age Publishing.

Billett, S. (2001). Learning through work: Workplace affordances and individual engagement. Journal of Workplace Learning, 13, 209-214.

Bliese, P. D. (2000). Within-group agreement, non-independence, and reliability: Implications for data aggregation and analysis. In K. J. Klein \& S. W. Kozlowski (Ed.), Multilevel theory, research, and methods in organizations (pp. 349-381). San Francisco, CA: Jossey-Bass.

Bryk, A. \& Raudenbush, S. W. (1992). Hierarchical linear models for social and behavioral research: Applications and data analysis methods. Newbury Park, CA: Sage.

Curry, L. A., Snyder, C. R., Cook, D. L., Ruby, B. C. \& Rehm, M. (1997). The role of hope in student-athlete academic and sport achievement. Journal of Personality and Social Psychology, 73, 1257-1267.

Deci, E. L., Gagné, M., Ryan, R. M., Leone, D. L., Usunov, J. \& Kornazheva, B. P. (2001). Need satisfaction, motivation and well-being in the work organizations of a former eastern bloc country: A crosscultural study of self-determination. Personality and Social Psychology Bulletin, 27, 930-942.

Deci, E. L. \& Ryan, R. M. (1985a). Intrinsic motivation and self-determination in human behavior. New York: Plenum.

Deci, E. L. \& Ryan, R. M. (1985b). The general causality orientations scale: Self-determination in personality. Journal of Research in Personality, 19, 109-134.

Deci, E. L., Connell, J. P., \& Ryan, R. M. (1989). Self-determination in a work organization. Journal of Applied Psychology, 74, 580-590.

Deci, E. L. \& Ryan, R. M. (2000). The "what» and "why» of goal pursuits: Human needs and the self-determination of behavior. Psychological Inquiry, 11, 227-268.

Deci, E. L. \& Ryan, R. M. (2008). Facilitating optimal motivation and psychological well- 
being across life's domains. Canadian Psychology, 49, (1), 14-23.

Dweck, C. (1986). Motivational processes affecting learning. American Psychologist, 41, $1040-1048$.

Enders, C. K. \& Bandalos, D. L. (2001). The relative performance of full information maximum likelihood estimation for missing data in structural equation models. Structural Equation Modelling, 8, 430-457.

Frey, A. \& Balzer, L. (2005). Der Beurteilungsbogen smk: Ein Messverfahren für die Diagnose von sozialen und methodischen Fähigkeitskonzepten. In A. Frey, R. S. Jäger \& U. Renold (Ed.). Kompetenzdiagnostik - Theorien und Methoden zur Erfassung und Bewertung von beruflichen Kompetenzen (pp. 31-56). Landau: Verlag Empirische Pädagogik.

Gagné, M. \& Deci, E. L. (2005). Self-determination theory and work motivation. Journal of Organizational Behavior, 26, 331-362.

Gagné, M., Koestner, R. \& Zuckerman, M. (2000). Facilitating the acceptance of organizational change: the importance of self-determination. Journal of Applied Social Psychology, 30, 1843-1852.

Greguras, G. J. \& Diefendorff, J. M. (2009). Different fits satisfy different needs: Linking person-environment fit to employee commitment and performance using self-determination theory. Journal of Applied Psychology, 94, 465-477.

Hackman, J. R. \& Oldham, G. R. (1975). Development of the job diagnostic survey. Journal of Applied Psychology, 60, 159-170.

Ilardi, B. C., Leone, D., Kasser, T. \& Ryan, R. M. (1993). Employee and supervisor ratings of motivation: Main effects and discrepancies associated with job satisfaction and adjustment in a factory setting. Journal of Applied Social Psychology, 23, 1789-1805.

Lawler, E. E. (1992). The ultimate advantage: Creating the high involvement organization. San Francsico, CA: Jossey-Bass.

Lopez, S. J., Snyder, C. R., Magyar-Moe, J., Edwards, L. M., Pedrotti, J. T., Janowski, K., Turner, J. L. \& Pressgrove, C. (2004). Strategies for accentuating hope. In P. A. Linley \& S. Joseph (Ed.), Positive psychology in practice (pp. 388-404). Hoboken, NJ: John Wiley \& Sons.

Lüdtke, O., Trautwein, U., Kunter, M. \& Baumert, J. (2006a). Reliability and agreement of student ratings of the classroom environment: A reanalysis of TIMSS data. Learning Environment Research, 9, 215-230.

Lüdtke, O., Trautwein, U., Kunter, M. \& Baumert, J. (2006b). Analyse von Lernumwelten: Ansätze zur Bestimmung der Reliabilität und Übereinstimmung von Schülerwahrnehmungen. Zeitschrift für Pädagogische Psychologie, 20, 85-96.

Luthans, F., Avolio, B. J., Avey, J. B. \& Norman, S. M. (2007). Psychological capital: Measurement and relationship with performance and satisfaction. Personnel Psychology, 60, 541-572.

Luthans, F., Avolio, B., Walumbwa, F. \& Li, W. (2005). The psychological capital of Chinese workers: Exploring the relationship with performance. Management and Organization Review, 1, 247-269.

Luthans, F. \& Jensen, S. M. (2002). Hope: A new positive strength for human resource development. Human Resource Development Review, 1, (3), 304-322.

Luthans, F., Norman, S. M., Avolio, B. J. \& Avey, J. B. (2008). The mediating role of psychological capital in the supportive organizational climate - employee performance relationship. Journal of Organizational Behavior, 29, 219-238.

Luthans, F., Youssef, C. M. \& Avolio, B. J. (2007). Psychological capital. New York: Oxford University Press.

Magaletta, P. R. \& Oliver, J. M. (1999). The hope construct, will and ways: Their relations with self-efficacy, optimism and generalized well-being. Journal of Clinical Psychology, 55, (5), 539-551.

McDermott, D. \& Hastings, S. (2000). Children: Raising Future Hopes. In C. R. Snyder (Ed.), Handbook of hope: Theory, measures, and applications (pp. 25-57). San Diego, CA: Academic Press. 
Meyer, J. M. \& Gagné, M. (2008). Employee engagement from a self-determination theory perspective. Industrial and Organizational Psychology, 1, 60-62.

Millette, V. \& Gagné, M. (2008). Designing volunteers' tasks to maximize motivation, satisfaction and performance: The impact of job characteristics on volunteer engagement. $M o-$ tivation and Emotion, 32, (1), 11-22.

Papaioannou, A., Marsh, H. W. \& Theodorakis, Y. (2004). A multilevel approach to motivational climate in physical education and sport settings: An individual or a group level construct? Journal of Sport \& Exercise Psychology, 26, 90-118

Park, N., Peterson, C. \& Seligman, M. E. P. (2004). Strengths of character and well-being: Look at hope and modesty. Journal of Social \& Clinical Psychology, 23, (5), 603-619.

Pekrun, R., Elliot, A. \& Maier, M. (2009). Achievement goals and achievement emotions: Testing a model of their joint relations with academic performance. Journal of Educational Psychology, 101, 115-135.

Peterson, C. \& Park, N. (2006). Character strengths in organizations. Journal of Organizational Behavior, 27, 1149-1154.

Peterson, C. \& Seligman, M. E. P. (2004). Character strengths and virtues: A classification and handbook. New York: Oxford University Press.

Peterson, S. J. \& Byron, K. (2008). Exploring the role of hope in job performance: Results from four studies. Journal of Organizational Behavior, 29, (6), 785-803.

Raudenbush, S. W. \& Bryk, A. S. (2002). Hierarchical linear models: Applications and data analysis methods. Thousand Oaks, CA: Sage.

Raudenbush, S. W., Bryk, A. S., Cheong, Y. F. \& Congdon, R. (2004). HLM 6: Hierarchical linear and nonlinear modeling. Chicago, IL: Scientific Software International (SSI).

Raykov, T. (2005). Analysis of longitudinal studies with missing data using covariance structure modeling with full-information maximum likelihood. Structural Equation Modeling, 12, 493-505.

Rego, A., Machado, F., Leal, S. \& Cunha, M. P. E. (2009). Are hopeful employees more creative? An empirical study. Creativity Research Journal, 21, (2), 223-231.

Rogers, C. R. (1961). On becoming a person. Boston: Houghton Mifflin.

Ryan, R. M. \& Deci, E. L. (2000). Self-determination theory and the facilitation of intrinsic motivation, social development, and well-being. American Psychologist, 55, 68-78.

Ryan, R. M. \& Deci, E. L. (2006). Self-regulation and the problem of human autonomy: Does psychology need choice, self-determination, and will? Journal of Personality and Social Psychology, 74, (6), 1557-1586.

Scharnhorst, U., Frey, A. \& Balzer, L. (2006). Qualitätsmerkmale und ihre Wirkung in der betrieblichen Berufsbildung (QuWibB). Unpublished research report, Swiss federal institute for vocational education and training, Zollikofen, Switzerland.

Seligman, M. E. P. \& Csikszentmihalyi, M. (2000). Positive psychology. American Psychologist, 55, (1), 5-14.

Shavelson, R. J., Hubner, J. J. \& Stanton, G. C. (1976). Self-concept: Validation of construct interpretations. Review of Educational Research, 46, 407-441.

Sheldon, K. M. \& Elliot, A. J. (1999). Goal striving, need satisfaction, and longitudinal wellbeing: The self-concordance model. Journal of Personality and Social Psychology, 76, 482-497.

Shorey, H. S., Snyder, C. R., Yang, X. \& Lewin, M. R. (2003). The role of hope as a mediator in recollected parenting, adult attachment, and mental health. Journal of Social and Clinical Psychology, 22, 685-715.

Simmons, B. L., Gooty, J., Nelson, D. L. \& Little, L. M. (2009). Secure attachments: Implications for trust, hope, burnout, and performance. Journal of Organizational Behavior, 30, 233-247.

Sirsch, U., Dreher, E., Mayr, E. \& Willinger, U. (2009). What does it take to be an adult in Austria? Views of adulthood in Austrian adolescents, emerging adults, and adults. Journal of Adolescent Research, 24, 275-292.

Snijders, T. A. B. \& Bosker, R. J. (1999). Multilevel analysis: An introduction to basic and advanced multilevel modeling. London: Sage. 
Snyder, C. R. (1995). Conceptualizing, measuring, and nurturing hope. Journal of Counseling and Development, 73, 355-360.

Snyder, C. R. (2000a). Genesis: Birth and growth of hope. In C. R. Snyder (Ed.), Handbook of hope: Theory, measures, and applications (pp. 25-57). San Diego, CA: Academic Press.

Snyder, C. R. (2000b). Hypothesis: There is hope. In C. R. Snyder (Ed.), Handbook of hope: Theory, measures, and applications (pp. 3-21). San Diego, CA: Academic Press.

Snyder, C. R. (2002). Hope: Rainbows in the mind. Psychological Inquiry, 13, 249-275.

Snyder, C. R. \& Feldman, D. (2000). Hope for the many: An empowering social agenda. In C. R. Snyder (Ed.), Handbook of hope: Theory, measures, and applications (pp. 389-412). San Diego, CA: Academic Press.

Snyder, C. R., Harris, C., Anderson, J. R., Holleran, S. A., Irving, L. M., Sigmon, S. T., Yoshinobu, L., Gibb, J., Langelle, C. \& Harney, P. (1991). The will and the ways: Development and validation of an individual-differences measure of hope. Journal of Personality and Social Psychology, 60, (4), 570-585.

Snyder, C. R. \& Lopez, S. J. (Ed.). (2009). Handbook of positive psychology. New York: Oxford University Press.

Snyder, C. R., Shorey, H., Cheavens, J., Pulvers, K. M., Adams,V. H., III \& Wiklund, C. (2002). Hope and academic success in college. Journal of Educational Psychology, 94, $820-826$.

Sumerlin, J. (1997). Self-actualization and hope. Journal of Social Behavior and Personality, 12, 1101-1110.

Wandeler, C. (2003). Unemployment and mental health. Unpublished Master Thesis (Lizenziatsarbeit), University of Fribourg, Switzerland.

Williams, G. C., Gagné, M., Ryan, R. M. \& Deci, E. L. (2002). Facilitating autonomous motivation for smoking cessation. Health Psychology, 21, 40-50.

Wandeler, C. \& Bundick, M. J. (2011). The development of hope at the workplace. Journal of Positive Psychology, 6, 341-354.

Wandeler, C., Lopez, S. \& Baeriswyl, F. (in press). Hope, mental health, and development of vocational competencies in vocational training. Journal of Vocational Education and Training Research.

Key words: Hope, self-determination, autonomy-support, work, vocational education and training

\section{"Hope", Selbstbestimmung und berufliches Lernen : eine Mehrebenenanalyse in der Berufsbildung}

\section{Zusammenfassung}

Die vorliegende Studie untersuchte die Hoffnung von jungen Erwachsenen im Kontext einer vier jährigen beruflichen Ausbildung. Basierend auf der Verbindung von Theorien zu Hoffnung und Selbstbestimmung wurde eine Theorie über hoffnungsfördernde berufliche Umweltbedingungen entwickelt. Dabei wird ein Zusammenhang zwischen allgemeiner Hoffnung und der Befriedigung der drei psychischen Grundbedürfnisse (Autonomie, Kompetenz und Verbundenheit) im beruflichen Lernumfeld postuliert. Die Querschnittsfragebogendaten umfassen / erfassen die Perspektive von 450 Lehrlingen und 58 Ausbildenden. Die Ergebnisse der Mehrebenenanalysen unterstützen die postulierte positive Beziehung zwischen Hoffnung und den drei psychischen Grundbedürfnissen im Arbeitsumfeld. Praktische Empfehlungen der Studie zielen unter an- 
derem auf die Schaffung von autonomieunterstützenden Arbeitsbedingungen, um die Befriedigung der psychischen Grundbedürfnisse zu erleichtern und so auch die Entwicklung von Hoffnung zu fördern.

Schlagworte: Hoffnung, Selbstbestimmung, berufliche Bildung, Autonomie, Kompetenz

\section{Espoir, autodétermination et apprentissage en emploi: une étude multi-niveaux en contexte de formation professionnelle} Résumé

Cette contribution examine l'espoir des étudiants apprentis en contexte de formation professionnelle duale de 4 ans. En référence à la théorie de l'espoir combinée avec les idées fondamentales de la théorie de l'autodétermination, l'hypothèse principale prédit une corrélation positive entre l'espoir des apprentis et la satisfaction de leurs besoins psychologiques de base (besoin de relation, d'autonomie et de compétence) que leur procure leur place de travail. L'analyse multi-niveaux des données recueillies par questionnaire comprend les perceptions de 508 apprentis au niveau individuel et au niveau de leur groupe d'appartenance, ainsi que ceux de leurs formateurs. Les résultats confirment notre hypothèse puisqu'une part importante de la variance de l'espoir individuel est liée au sentiment que l'environnement professionnel de la formation satisfait les trois besoins psychologiques de base. L'article conclut en recommandant la création d'environnements de travail centrés à la fois sur le soutien et l'autonomie dans le but d'infléchir le sentiment de satisfaction et d'espoir des étudiants apprentis.

Mots clés: Espoir, autodétermination, besoins psychologiques, soutien à l'autonomie, formation professionnelle duale

\section{Speranza, autodeterminazione e apprendimento sul posto di lavoro: uno studio multilivello nella formazione professionale}

\section{Riassunto}

Questo studio indaga la speranza nel contesto di un programma quadriennale di formazione professionale. Il quadro teorico combina la teoria della speranza con le idee chiave della teoria dell'autodeterminazione. L'ipotesi principale è che esista una relazione positiva tra la speranza generale e la soddisfazione di bisogno psicologici di base durante l'apprendimento e sul posto di lavoro.

L'analisi dei dati di un questionario compilato da 450 studenti e 58 formatori integra le prospettive degli studenti a livello individuale e di gruppo, e le prospettive dei formatori, usando un modello multilivello. I risultati mostrano che una larga parte della variazione nella speranza individuale è associata all'ambiente di 
apprendimento, e offrono sostegno empirico all'ipotesi della relazione positiva tra speranza e soddisfazione di tre bisogni psicologici di base (relazione, autonomia, competenza) sul posto di lavoro. L'articolo si conclude raccomandando la creazione di ambienti di lavoro che promuovono l'autonomia per facilitare la soddisfazione dei bisogni psicologici di base e sostenere la speranza.

Parole chiave: Speranza, autodeterminazione, autonomia-supporto, lavoro, formazione professionale

\section{Appendix}

German Translation of the Trait Hope Scale for Adults (without distractor items)

\begin{tabular}{|l|c|}
\hline \multicolumn{1}{|c|}{ ITEM } & SUBSCALE \\
\hline $\begin{array}{l}\text { 1. Ich kann mir viele Wege vorstellen, aus einer problematischen Situation } \\
\text { herauszukommen. }\end{array}$ & $\mathrm{P}$ \\
\hline 2. Ich verfolge meine Ziele mit Energie. & $\mathrm{A}$ \\
\hline 3. Für jedes Problem gibt es viele verschiedene Lösungen. & $\mathrm{P}$ \\
\hline $\begin{array}{l}\text { 4. Ich kann mir viele Wege vorstellen, die Dinge zu erreichen, die mir im } \\
\text { Leben am wichtigsten sind. }\end{array}$ & $\mathrm{P}$ \\
\hline $\begin{array}{l}\text { 5. Selbst wenn andere den Mut verlieren, weiss ich, dass ich einen Weg fin- } \\
\text { den kann, das Problem zu lösen. }\end{array}$ & $\mathrm{P}$ \\
\hline $\begin{array}{l}\text { 6. Meine vergangenen Erfahrungen im Leben haben mich gut für meine } \\
\text { Zukunft vorbereitet. }\end{array}$ & $\mathrm{A}$ \\
\hline 7. Ich war bis jetzt sehr erfolgreich im Leben.* & $\mathrm{A}$ \\
\hline 8. Ich erreiche die Ziele, die ich mir gesetzt habe. & $\mathrm{A}$ \\
\hline
\end{tabular}

$\mathrm{P}=$ Pathways (Ways) Subscale

$\mathrm{A}=$ Agency (Will) Subscale

* The initial back-translated version was "Ich war bis jetzt ziemlich erfolgreich im Leben." During pretesting participants frequently commented that "pretty successful" was very vague and easy to agree with. The statement in the item was thus formulated more strongly. 